\title{
Terpenic subfraction of Pterodon pubescens induces apoptosis of K562 leukemic cells by modulating gene expression
}

\author{
MONICA FARAH PEREIRA ${ }^{1}$, THIAGO MARTINO ${ }^{1}$, SERGIO RANTO DALMAU ${ }^{1}$, \\ RODOLPHO MATTOS ALBANO ${ }^{1}$, JEAN-PIERRE FÉRÉZOU ${ }^{2}$, SONIA SOARES COSTA ${ }^{3}$, \\ MARSEN GARCIA PINTO COELHO ${ }^{1}$ and KÁTIA COSTA CARVALHO SABINO ${ }^{1}$
}

\author{
${ }^{1}$ Departamento de Bioquímica, Instituto de Biologia Roberto Alcantara Gomes, Universidade do Estado \\ do Rio de Janeiro, Av. Professor Manoel de Abreu, 444, $4^{\circ}$ andar, CEP-20550-170 Rio de Janeiro, RJ, Brazil; \\ ${ }^{2}$ Laboratoire de Synthèse Organique, École Polytechnique, DCSO, Route de Saclay, F-91128 Palaiseau, Cedex, \\ France; ${ }^{3}$ Núcleo de Pesquisa em Produtos Naturais, Av. Carlos Chagas Filho, 373, Centro de Ciências \\ da Saúde Bloco H, CCS Laboratory H1-009-13, Ilha do Fundão, 21941-902 Rio de Janeiro, RJ, Brazil
}

Received June 30, 2010; Accepted August 18, 2010

DOI: 10.3892/or_00001063

\begin{abstract}
Deregulation of cell proliferation and apoptosis is linked to malignant cell development. Leukemia is the most frequent cancer in children, and plants are important sources for new potential anti-cancer agents. Although anti-tumoral effects have been shown for Pterodon pubescens extracts, the mechanisms are still obscure. This study describes in Pterodon pubescens a furane diterpene only reported in Pterodon polygalaeflorus, the methyl-6 $\alpha$-acetoxy-7ßhydroxyvouacapan-17ß-oate, indicated by HRMS and ${ }^{13} \mathrm{C}$ NMR analysis, and demonstrates some mechanisms of the anti-leukemia action of its terpene subfraction SF5. SF5 induced cytotoxic and anti-proliferative effects on K562 cells. Increased sub-G1 nuclei and Annexin $\mathrm{V}^{+}$-FITC cells confirmed apoptosis of leukemic cells by treatment of these cells with SF5. Down-regulation of DNMT1 gene transcription and over-expression of Apaf-1 mRNA suggested that SF5 may be inducing apoptosis of K562 cells by epigenetic up-regulation of pro-apoptotic proteins involved in the mitochondrial intrinsic pathway.
\end{abstract}

\section{Introduction}

Apoptosis appears to be an essential mechanism used by biological organisms to maintain cell number homeostasis but it is pivotal in the pathological process of several diseases

Correspondence to: Professor Kátia Costa de Carvalho Sabino, Departamento de Bioquímica - IBRAG - Universidade do Estado do Rio de Janeiro, Av. Professor Manoel de Abreu, 444, $4^{\circ}$ andar, CEP-20550-170 Rio de Janeiro, RJ, Brazil

E-mail: kasabino2000@yahoo.com.br

Key words: apoptosis, leukemia, Pterodon pubescens, apoptotic peptidase activating factor 1 , terpenes, DNA methyltransferase 1
(1). The development of a malignant cell is linked to deregulation of the balance between cell proliferation and apoptosis (2). Leukemia is the most frequent malignant disease in children. In spite of the great progress in this disease treatment, $20-30 \%$ of the patients still die of the disease.

DNA methylation is crucial for epigenetic control of gene transcription and the cell death by apoptosis involves complex processes under genetic and epigenetic regulation (3). An increased DNA methyltransferase 1 (DNMT1) expression has been reported in a certain amount of human cancers, which can be associated with the silencing of cell cycle inhibitors or pro-apoptotic mediators expression (4). Apoptosis is well characterized by features such as cell shrinking, chromatin condensation and membrane phosphatidylserine exposure $(4,5)$. There are many studies suggesting that the loss of mitochondrial transmembrane potential occurs earlier in the commitment phase of apoptosis which results in cytochrome $\mathrm{c}$ release, apoptosome assembly by interaction of cytochrome c with the apoptotic peptidase activating factor 1 (Apaf-1) in the cytosol, in the presence of ATP, and caspase 9 activation. Apaf-1 is a central component of the intrinsic pathway of apoptosis and caspase 9 activates the executioner caspase 3 and 7 , responsible for degradation of many cellular substrates (6). Since apoptosis occurs by a conserved and genetically programmed mechanism, it has generated a hope that selective intervention on this modulated process may influence the course of the major degenerative diseases and cancer. Many types of antitumor drug therapies exert their effect by activating apoptosis (2).

Natural products are important sources of new bioactive molecules with promising chemotherapeutic properties (7). A number of low molecular weight compounds are currently being investigated for their pharmacological properties in regulating apoptosis. Pterodon pubescens Benth., Leguminosae, popularly known as 'Sucupira branca', is found distributed throughout the central region of Brazil and is used in folk medicine to treat rheumatic and inflammatory diseases (8-10). Both pharmacological activities have already been scientifically demonstrated (11-13). Phytochemical studies 
of Pterodon pubescens described linear diterpenes geranylgeraniol and 14,15-epoxygeranylgeraniol in the seed oil with topic protection against Schistossoma mansoni invasion in mice by the latter (14). In 1970, two cyclic diterpenes with vouacapan skeletal were described (15). Later, several new diterpenes were described $(13,16,17)$. Anti-inflammatory effects have been reported for fractions derived from the ethanolic extract of Pterodon pubescens containing the diterpenes methyl-dihydroxy-vouacapan-oate, farnesol and geranylgeraniol (13). Growth inhibition and apoptosis of melanoma cells has also been demonstrated for the diterpene methyl-dihydroxy-vouacapan-oate (17). The present study describes important molecular mechanisms related to antileukemic effects of a terpenic subfraction from Pterodon pubescens $(\mathrm{Pp})$ and reports the major components in this mixture based on ${ }^{13} \mathrm{C}$-NMR and mass spectra (HRMS) analysis.

\section{Materials and methods}

Plant material. Pterodon pubescens seeds were collected by Luciana Pontes Coelho in Goiás, Brazil. The taxonomic identity was confirmed by Haroldo Cavalcante de Lima, at the Departamento de Botânica Sistemática, Jardim Botânico do Estado do Rio de Janeiro, Brazil, where a voucher of the collected specimen was deposited (RB 350279).

Extraction, fractioning and identification of methyl,6 $\alpha-$ acetoxy-7ß-hydroxyvouacapan-17ß-oate in SF5 subfraction. The seeds were powdered and submitted to $100 \%$ ethanol extraction $(15 \mathrm{~g} / 100 \mathrm{ml})$ at room temperature for 15 days. The oil (EEPp) obtained (50\% yield, w/w) after ethanol evaporation was fractionated by liquid-liquid partition chromatography using hexane. The EEPp was submitted to successive extractions with hexane. After solvent evaporation, the hexanic fraction (55\% yielding) was submitted to a column chromatography $(42 \times 2.5 \mathrm{~cm})$ on silica gel (Art. 7733 - Kieselgel 60, 35-70 MESH ASTM, Merck), eluted successively with hexane, hexane/dicloromethane $(1: 1)$, hexane/ethyl acetate (1:1), ethyl acetate, ethanol and $2 \%$ acetic acid in ethanol. After analysis of sample gas chromatography profiles, they were joined in eight sub-fractions. The most cytotoxic subfraction (SF5, 32.9\% yield) is a yellow, viscous and aromatic sample, and showed the presence of a furane diterpene, the methyl-6 $\alpha$-acetoxy-7ß-hydroxyvouacapan$17 ß$-oate (compound 1), not described previously in this species. Its identification was based on ${ }^{13} \mathrm{C}-\mathrm{NMR}$ spectra recorded on a Bruker spectrometer $\left({ }^{13} \mathrm{C}, 100.6 \mathrm{MHz}\right)$, using deuterated chloroform $\left(\mathrm{CDCl}_{3}\right)$ as solvent and internal standard $(\delta=0)$. The chemical shifts are expressed in parts per million $(\mathrm{ppm})$, reported from the central peak of deuterochloroform (77.16 ppm). Compound 1: $\delta_{\mathrm{C}} 39.27$ (C1), 18.28 (C2), 43.38 (C3), 33.13 (C4), 54.95 (C5), 75.54 (C6), 81.29 (C7), 42.53 (C8), 47.95 (C9), 38.71 (C10), 21.97 (C11), 150.46 (C12), 113.37 (C13), 46.37 (C14), 108.45 (C15), 141.42 (C16), 175.43 (C17), 36.18 (C18), 22.47 (C19), 15.46 (C20), 52.23 (C17-MeO). High resolution mass spectra (HRMS) for SF5 performed on a JEOL JMS-Gcmate II, GC/MS system spectrometer (direct probe; ionization mode; $\mathrm{EI}^{+}$): 404.2205 (measured mass) corresponding to the molecular formula $\mathrm{C}_{23} \mathrm{H}_{32} \mathrm{O}_{6}$ (calculated mass 404.2199), confirmed the presence of compound 1. Mass spectral fragmentations and ${ }^{13} \mathrm{C}-\mathrm{NMR}$ spectra of SF5 were compared to those of literature.

Biological assays. The human chronic myelogenous leukemia cell line K562 (CCL-243) was purchased from the American Type Culture Collection (ATCC) and was cultured in supplemented medium. The effects of SF5 on cells were evaluated (duplicates) by co-culture of cells with different SF5 concentration at $37^{\circ} \mathrm{C}$ and $5 \% \mathrm{CO}_{2}$. The SF5 sample was diluted with ethanol and then with RPMI-1640 medium, supplemented with $10 \%$ fetal bovine serum (Cultilab, Brazil), penicillin $(70 \mathrm{mg} / \mathrm{l})$ and streptomycin $(100 \mathrm{mg} / \mathrm{l})$, until the final concentration of $0.01 \%$ ethanol. Control cultures received only $0.01 \%$ ethanol in supplemented medium.

MTT cytotoxicity assay. K562 cells $\left(1 \times 10^{5} / \mathrm{ml}\right)$ were cultured (triplicates) in 96 flat-bottom-wells plates (Becton Dickinson Labware, USA), either in the absence or presence of different SF5 concentrations in a final volume of $100 \mu 1$. The plates were incubated for $34 \mathrm{~h}$, at $37^{\circ} \mathrm{C}$, with $5 \% \mathrm{CO}_{2}$. Thereafter, cell survival was determined by the MTT assay (18) adding $10 \mu \mathrm{l} /$ well of a $5 \mathrm{mg} / \mathrm{ml}$ stock solution of MTT (Sigma Chemical Co., St. Louis, MO, USA) in phosphatebuffered saline pH 7.4 (PBS). Following incubation for $2 \mathrm{~h}$, $100 \mu 1$ /well of SDS $10 \%$ solution with $0.01 \mathrm{~N} \mathrm{HCl}$ were added. The extent of formazan crystal production was measured by absorbance at $570 \mathrm{~nm}$ (microplate reader $\mu$ Quant, Bio-Tek Instruments, Inc.). Control cultures did not receive SF5.

Cell proliferation assay. The cells $\left(2.5 \times 10^{5} / \mathrm{ml}\right)$ were cultured in supplemented medium in 96-well flat-bottom plates (200 $\mu 1$ ), either in the absence or presence of different EEPp concentrations, for $36 \mathrm{~h}$, at $37^{\circ} \mathrm{C}$, in $5 \% \mathrm{CO}_{2}$ (triplicates). To assess DNA synthesis, $25 \mu \mathrm{l} /$ well of $10 \mu \mathrm{Ci} / \mathrm{ml}\left[{ }^{3} \mathrm{H}\right]$-methylthymidine $\left({ }^{3} \mathrm{H}-\mathrm{Tdr}\right.$; Amersham Biosciences, Brazil) were added at the beginning of the culture. Then, the cells were harvested on filter paper and processed for ${ }^{3} \mathrm{H}-\mathrm{Tdr}$ radioactivity determination by liquid scintillation.

Flow cytometric analysis of sub-G1 nucleus and cell shrinkage. $\mathrm{K} 562$ cells $\left(2.5 \times 10^{5} / \mathrm{ml}\right)$ were incubated either in the absence or presence of $30 \mu \mathrm{g} / \mathrm{ml}$ of SF5 or methotrexate (MTX) for $36 \mathrm{~h}$ at $37^{\circ} \mathrm{C}$ and $5 \% \mathrm{CO}_{2}$ and processed for different analyses. After treatment of cells with PI solution (final concentration $2 \mu \mathrm{g} / \mathrm{ml}$ ), cell death was evaluated by high membrane permeability to PI indicated by high fluorescence at $585 \mathrm{~nm}$. The cell shrinking was determined by analyzing cell size with the forward-scatter (FSC) parameter of the cytometer. Plots showing cell distribution accordingly to size (FSC) and granularity (SSC) (not shown) were used to delimit a region to avoid apoptotic bodies and cell debris in the analysis. To determine the sub-G1 nuclei, cells $\left(1 \times 10^{6}\right)$ were centrifuged (400 x g, $5 \mathrm{~min}$ ), suspended in $500 \mu 1$ DNA staining solution $(0.3 \%$ Triton $\mathrm{X}-100$ and $50 \mu \mathrm{g} / \mathrm{ml} \mathrm{PI}$ in $43 \mathrm{mM}$ citrate buffer solution $\mathrm{pH} 8.2$ ), and maintained for $15 \mathrm{~min}$ at room temperature in the dark. Later, the samples were treated with $500 \mu 1$ ribonuclease A $50 \mu \mathrm{g} / \mathrm{ml}$ (Sigma Chemical Co.) in $43 \mathrm{mM}$ citrate buffer $\mathrm{pH} 8.2$ for $15 \mathrm{~min}$ at room temperature 
Table I. Main peaks and respective fragment ions observed in the GC-MS analysis (chemical ionization/ $\mathrm{NH}_{3}$ ) of SF5.

\begin{tabular}{|c|c|c|c|}
\hline $\mathrm{R}_{\mathrm{t}}(\min )$ & $\mathrm{m} / \mathrm{z}$ & Compound & Ref. \\
\hline 4.74 & $238(\mathrm{M}+18)$ & Epoxyfarnesol isomer & $(13)$ \\
\hline 8.08 & $272(\mathrm{M}-18)^{\mathrm{a}}$ & Geranylgeraniol derivative & $(14)$ \\
\hline 13.50 & $342(\mathrm{M}) ; 343(\mathrm{M}+1) ; 360(\mathrm{M}+18)$ & 7ß-acetoxy vouacapan derivative & $(16)$ \\
\hline 14.23 & $404(\mathrm{M}) ; 405(\mathrm{M}+1) ; 422(\mathrm{M}+18)$ & Methyl $6 \alpha$-acetoxy $7 ß$-hydroxyvouacapan $17 ß$-oate & $(20)$ \\
\hline 14.60 & $464(\mathrm{M}+18)^{\mathrm{b}}$ & $6 \alpha, 7 ß$-diacetoxy vouacapan $14 ß$-oate & $(16)$ \\
\hline
\end{tabular}

The results are expressed in retention time $\left(\mathrm{R}_{\mathrm{t}} \mathrm{min}\right)$ and $\mathrm{m} / \mathrm{z}$. ${ }^{\mathrm{a}}$ Molecular ion $(\mathrm{M}=290 \mathrm{~m} / \mathrm{z})$ not observed. ${ }^{\mathrm{b}} \mathrm{Molecular}$ ion $(\mathrm{M}=446 \mathrm{~m} / \mathrm{z}) \mathrm{not}$ observed.

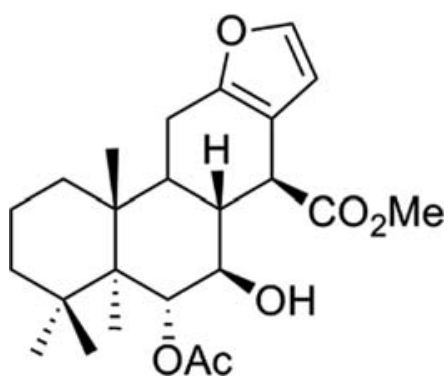

Figure 1. Chemical structure of the methyl-6 $\alpha$-acetoxy-7ß-hydroxyvouacapan17ß-oate (compound 1).

and the PI fluorescence measured. One hundred thousand events per sample were evaluated using a FACSCalibur cytometer (Becton Dickinson Labware). The excitation wavelength for PI was $488 \mathrm{~nm}$ and the emission was detected at $585 \pm 15 \mathrm{~nm}(19)$. Analysis was done with WinMdi 2.8 software.

Annexin $V^{+}$-FITC flow cytometric assay. K562 cells $\left(2.5 \times 10^{5} / \mathrm{ml}\right)$ were incubated either in the absence or presence with $50 \mu \mathrm{g} / \mathrm{ml}$ of SF5 or MTX for $36 \mathrm{~h}$ at $37^{\circ} \mathrm{C}$ and $5 \% \mathrm{CO}_{2}$. Phosphatidylserine (PS) exposure on plasmatic membrane of apoptotic cells was determined by Annexin- $\mathrm{V}$ labeling, according to the manufacturer's instructions (Annexin V-FITC apoptosis kit, BD Pharmingen, CA, USA). Briefly, cells $\left(1 \times 10^{6}\right)$ were washed twice with cold PBS and suspended in $1 \mathrm{ml}$ binding buffer. Cells $\left(1 \times 10^{5}, 100 \mu 1\right)$ were treated with Annexin V $(5 \mu \mathrm{l})$ and $50 \mu \mathrm{g} / \mathrm{ml}$ PI solution $(10 \mu \mathrm{l})$ for $15 \mathrm{~min}$ at room temperature. After addition of $400 \mu 1$ of binding buffer, cells $\left(5 \times 10^{4}\right)$ were acquired by Cell QuestPRO software and analyzed using WinMdi 2.8 software. Annexin V-FITC emission was determined by FITC fluorescence detection at $535 \pm 15 \mathrm{~nm}$ and PI at $>670 \mathrm{~nm}$ by flow cytometry. Annexin V positive cells were considered apoptotic cells. Apoptotic bodies and cell debris were avoided as possible from analysis.

$m R N A$ expression analysis by RT-PCR. Total RNA was extracted from various cell samples using TRIzol reagent according to the manufacturer's instructions (Invitrogen). The RNA concentration was determined by optical density at $260 \mathrm{~nm}$. Samples were treated with DNAse I and RNA integrity was confirmed by agarose gel electrophoresis.
Reverse transcription reaction was performed using MMLV reverse transcriptase (Invitrogen) with $2 \mu \mathrm{g}$ of total RNA in a $30 \mu 1$ reaction mixture containing random hexamers as primers. The cDNA was brought into $25 \mu 1$ mixture of PCR buffer, $0.2 \mathrm{mM}$ of each dNTP, $1.5 \mathrm{mM} \mathrm{MgCl}_{2}, 3.2 \mu \mathrm{g}$ of each primer, and 2.0 units of Taq DNA polymerase platinum (Invitrogen). The primers, annealing temperature of each primer and cycles used were: $\beta$-actin forward primer: 5 '-TCC TGTGGCATCCACGAAACT-3', reverse primer: 5'-GAA GCATTTGCGGTGGACGAT-3' (59 ${ }^{\circ} \mathrm{C}, 30$ cycles, $\left.314 \mathrm{pb}\right)$; Apaf-1 reverse primer: 5'-TTGCTGCCCTTCTCCATGAT-3', reverse primer: 5'-TCCCAACTGAAACCCAATGC-3' $\left(55^{\circ} \mathrm{C}, 30\right.$ cycles, $\left.334 \mathrm{pb}\right)$; DNMT1 reverse primer: 5'-GAT TTGTCCTTGGAGAACGG-3', reverse primer: TTGGG TGTTGGTTCTTTGGTT-3' (57 ${ }^{\circ} \mathrm{C}, 30$ cycles, 499 pb). All genes examined were normalized to a housekeeping gene encoding $B$-actin. PCR was performed in a Perkin Elmer GeneAmp PCR system 9600. Each PCR cycle consisted of denaturation at $94^{\circ} \mathrm{C}$ for $30 \mathrm{sec}$, annealing at specific annealing temperature for $30 \mathrm{sec}$, and extension at $72^{\circ} \mathrm{C}$ for $1 \mathrm{~min}$. Under the conditions used, the cDNAs were exponentially amplified, and thus a semiquantitative estimation of the products was allowed by $2 \%$ agarose gel electrophoresis. Band intensities were quantified by using Lab Image software (Germany).

Statistical analysis. Significant differences between pairs of groups were accessed using Student's t-test, with a significance level set at $\mathrm{p}<0.05$.

\section{Results}

${ }^{13} \mathrm{C}-\mathrm{NMR}$ and HRMS analysis. The major components of SF5, listed in Table I, were determined with basis on spectral fragmentation analysis and its comparison to data described in literature $(13,14,16,20)$. The presence of compound 1 , the methyl-6 $\alpha$-acetoxy-7ß-hydroxyvouacapan-17ß-oate $\left(\mathrm{C}_{23} \mathrm{H}_{32} \mathrm{O}_{6}\right)$ was confirmed in SF5 by ${ }^{13} \mathrm{C}$-NMR analysis comparing to data from Pterodon polygalaeflorus (16). This compound is described here for the first time in Pterodon pubescens. Its chemical structure is shown in Fig. 1.

SF5 effects on cell proliferation and cytotoxicity. SF5 inhibited the incorporation of DNA synthesis in all tested concentrations (Fig. 2A). The inhibition index $(\mathrm{p}<0.0001)$ ranged from 40.3 to 

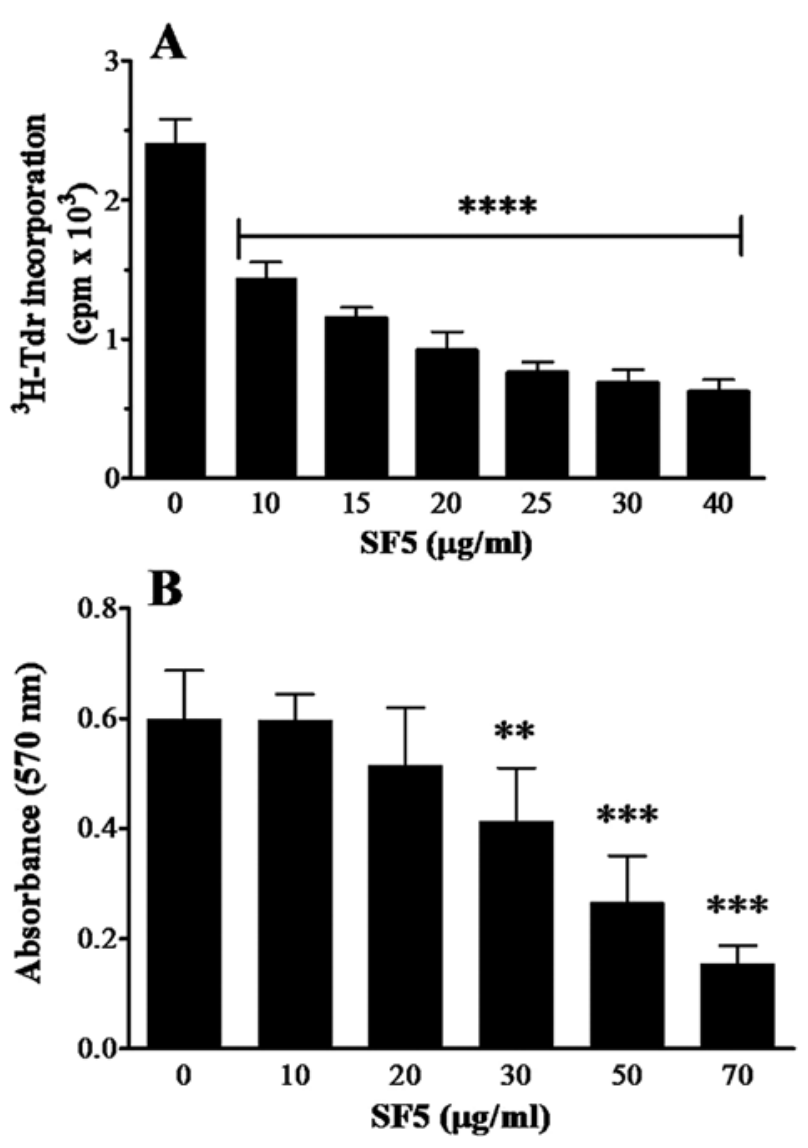

Figure 2. Effect of hexanic subfraction SF5 on K562 cell proliferation. (A) DNA synthesis; (B) mitochondrial reduction activity. Cells were treated either in the absence (control) or presence of different SF5 concentrations for $36 \mathrm{~h}$. Cell proliferation was determined by ${ }^{3} \mathrm{H}-\mathrm{Tdr}$ incorporation into DNA. Cell survival was determined by the MTT assay. Results represent the mean $\pm \mathrm{SD}$ of three and two independent experiments, respectively, in triplicate. ${ }^{* *} \mathrm{p}<0.01,{ }^{* * *} \mathrm{p}<0.001$, and ${ }^{* * * *} \mathrm{p}<0.0001$ related to control by Student's t-test.

$74.2 \%$ when cells were treated with 10 and $40 \mu \mathrm{g} / \mathrm{ml}$ of SF5, respectively. SF5 cytotoxicity to leukemic cells was concentration dependent (Fig. 2B). Cell viability was significantly reduced to 70,44 and $26 \%$, when treated with SF5 at 30, 50 and $70 \mu \mathrm{g} / \mathrm{ml}$, respectively.

SF5 effects on leukemic cell death. Treatment of K562 cells for $36 \mathrm{~h}$ with $30 \mu \mathrm{g} / \mathrm{ml} \mathrm{SF5}$ increased from $3.9 \%$ (control culture) to $29.5 \%$ (treated cells) the percentage of cells with high PI fluorescence (Fig. 3A, right marker), meaning high membrane permeability to PI and cell commitment to death. The analysis of cell size histograms shows that SF5 at $30 \mu \mathrm{g} / \mathrm{ml}$ increased the number of cells with reduced size (shrunken), a morphologic feature of cell apoptosis, compared to the control culture (Fig. 3B). The relative number of shrinking cells (apoptotic) after treatment with SF5 increased from 6.9\% (control) to 26.7. Methotrexate, a positive drug control, showed lower effects than SF5.

SF5 effects on the leukemia cell apoptosis. To confirm the apoptotic status, the percentage of nuclei with sub-G1 DNA content was determined by flow cytometry after treatment with SF5 $(30 \mu \mathrm{g} / \mathrm{ml})$ for $36 \mathrm{~h}$. SF5 increased from $3.8 \%$

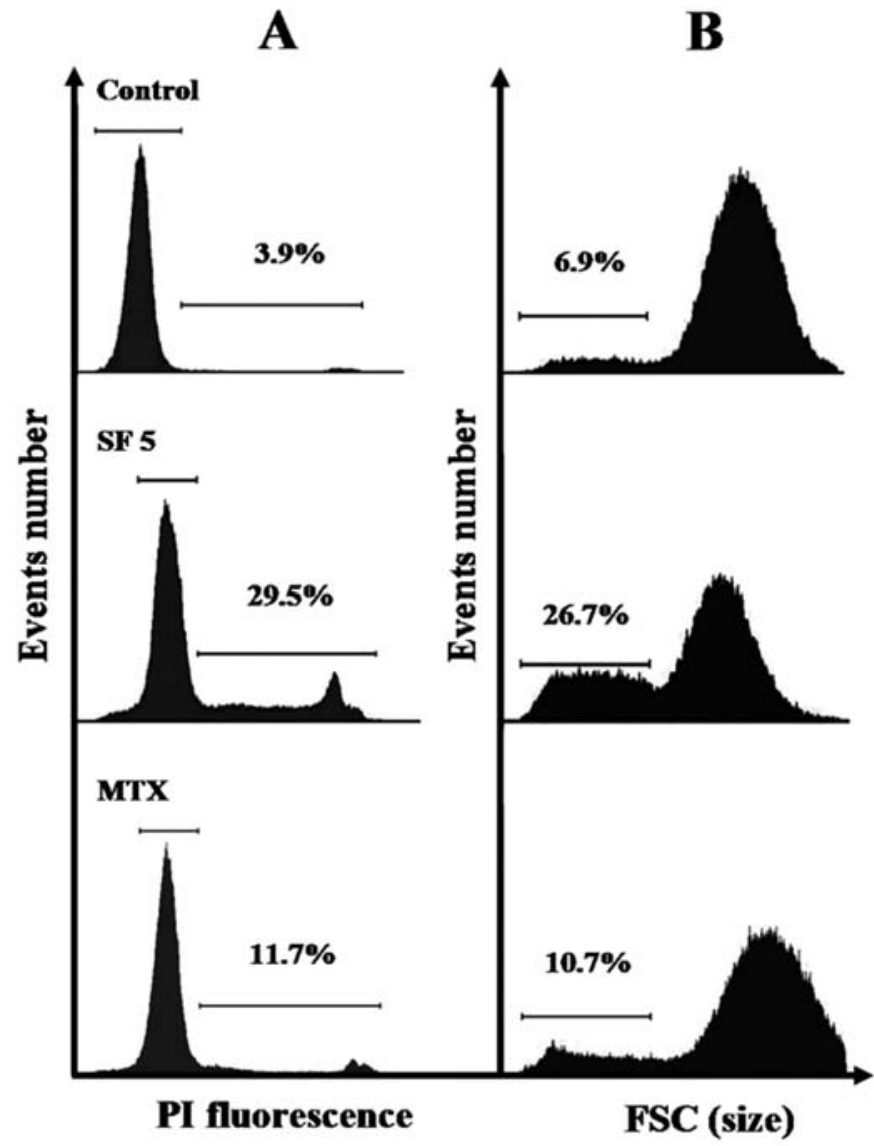

Figure 3. Effects of SF5 hexanic subfraction on K562 cell size and membrane permeability by flow cytometry. (A) PI fluorescence histograms; (B) Cell size histograms. Cells $\left(2.5 \times 10^{5} / \mathrm{ml}\right)$ were cultured in the absence (control) or presence of $30 \mu \mathrm{g} / \mathrm{ml} \mathrm{SF} 5$ or methotrexate (MTX) for $36 \mathrm{~h}$ and processed as described in Materials and methods. Representative results from three independent experiments.

(untreated cells, Fig. 4A) to $16.3 \%$ (Fig. 4B) the number of cells with sub-G1 DNA content. Methotrexate $(30 \mu \mathrm{g} / \mathrm{ml})$ induced effect similar to SF5 (18.9\%, Fig. 4C). Results from three independent experiments (Fig. 4D) showed increased number (by 14- or 9-fold) of sub-G1 nucleus following treatment with SF5 or MTX, respectively. Induction of apoptosis by SF5 treatment was also confirmed by PS exposure on the outer side of plasma membrane of K562 cell, determined by Annexin V labeling. Cells treated with SF5 $(50 \mu \mathrm{g} / \mathrm{ml})$ for $36 \mathrm{~h}$ showed considerable increase in Annexin V-positive cells (Fig. 5B), compared to untreated ones (Fig. 5A). The number of Annexin V-positive cells after treatment with MTX was lower than that of SF5. Results from three experiments confirm the K562 cell apoptosis by treatment with SF5 (Fig. 5D).

SF5 effects on Apaf-1 and DNMT1 gene expression by RT$P C R$. In order to approach some molecular mechanisms involved in this process cells were incubated in the absence or presence of SF5 $50 \mu \mathrm{g} / \mathrm{ml}$ for different times and then the total mRNA was isolated for RT-PCR analysis of regulatory molecules. Apaf-1 is a protein involved in the mitochondrial pathway of apoptosis activation (intrinsic pathway) and its promoter gene is regulated by methylation. DNA methyl- 

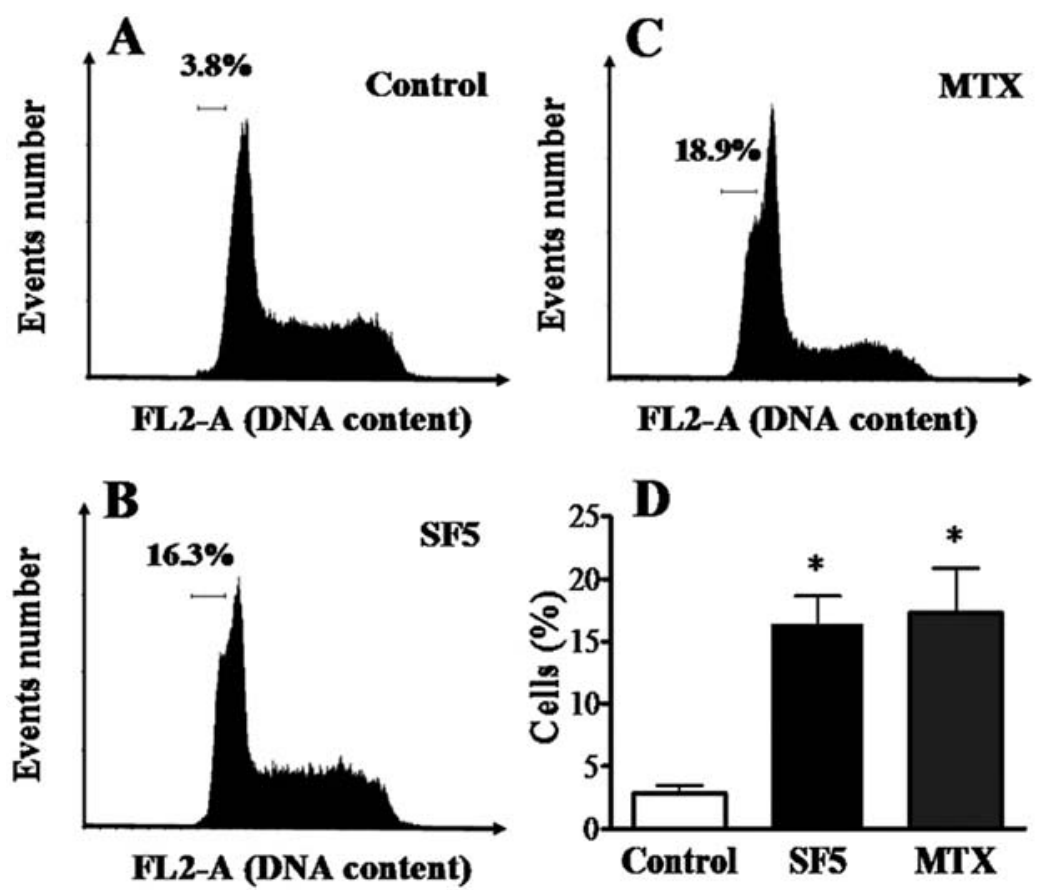

Figure 4. K562 cells apoptosis by flow cytometric analysis of sub-G1 nucleus of K562 cells treated with SF5 hexanic subfraction. Histograms of DNA content: (A) Control, (B) SF5, and (C) MTX treated cells; (D) relative number of sub-G1 nuclei fraction (mean \pm SD of three independent experiments). Cells $\left(2.5 \times 10^{5} / \mathrm{ml}\right)$ were cultured in the absence (control) or presence of $30 \mu \mathrm{g} / \mathrm{ml} \mathrm{SF} 5$ or methotrexate (MTX) for $36 \mathrm{~h}$ and processed as described in Materials and methods. " $\mathrm{p}<0.05$ and related to control by Student's t-test.

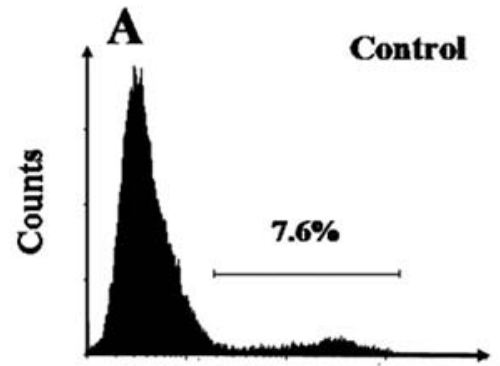

FL1-Anexin V

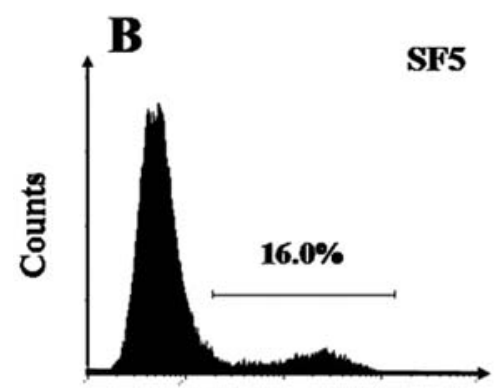

FL1-Anexin V

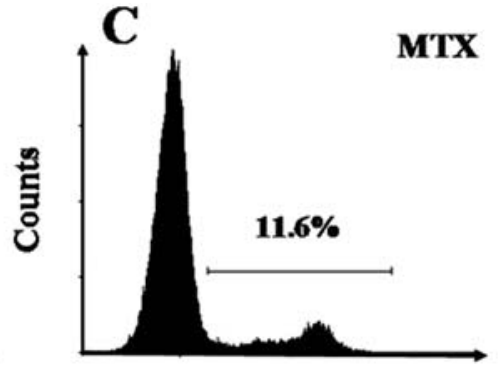

FL1-Anexin V

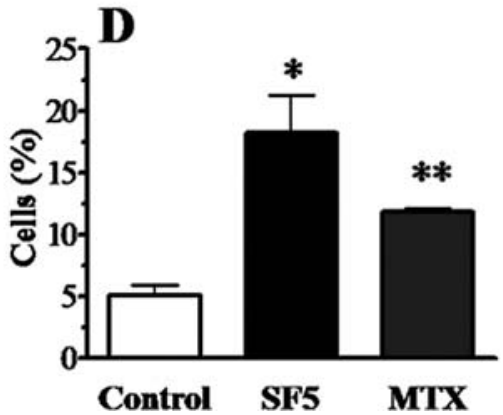

Figure 5. K562 cells apoptosis by flow cytometric analysis of phosphatidylserine exposure on cell membrane by Annexin V-FITC labeling, after treatment with SF5 hexanic subfraction. Histograms of Annexin V-FITC labeled cells: (A) Control, (B) SF5, and (C) MTX treated cells; (D) relative number of Annexin V-FITC positive cells (mean \pm SD from three independent experiments). Cells $\left(2.5 \times 10^{5} / \mathrm{ml}\right)$ were cultured in the absence (control) or presence of $50 \mu \mathrm{g} / \mathrm{ml} \mathrm{SF5}$ or methotrexate (MTX) for $36 \mathrm{~h}$ and processed as described in Materials and methods. ${ }^{*} \mathrm{p}<0.05$ and ${ }^{* *} \mathrm{p}<0.01 \mathrm{related}$ to control by Student's t-test.

transferases (DNMTs) hypermethylate the DNA resulting in silencing of gene expression. Treatment with SF5 for 12, 24 and $36 \mathrm{~h}$ caused a progressive increase of Apaf-1 and decrease of DNMT1 mRNA level, as can be observed by agarose gel electrophoresis and densitometric analysis using the $\beta$-actin as the housekeeping gene (Fig. 6).

\section{Discussion}

Chemotherapeutic drugs induce apoptosis of tumor cells through different mechanisms, in which signaling events play an important role depending upon the cell type and stimulus (2), but there are few studies on natural compounds. As SF5 


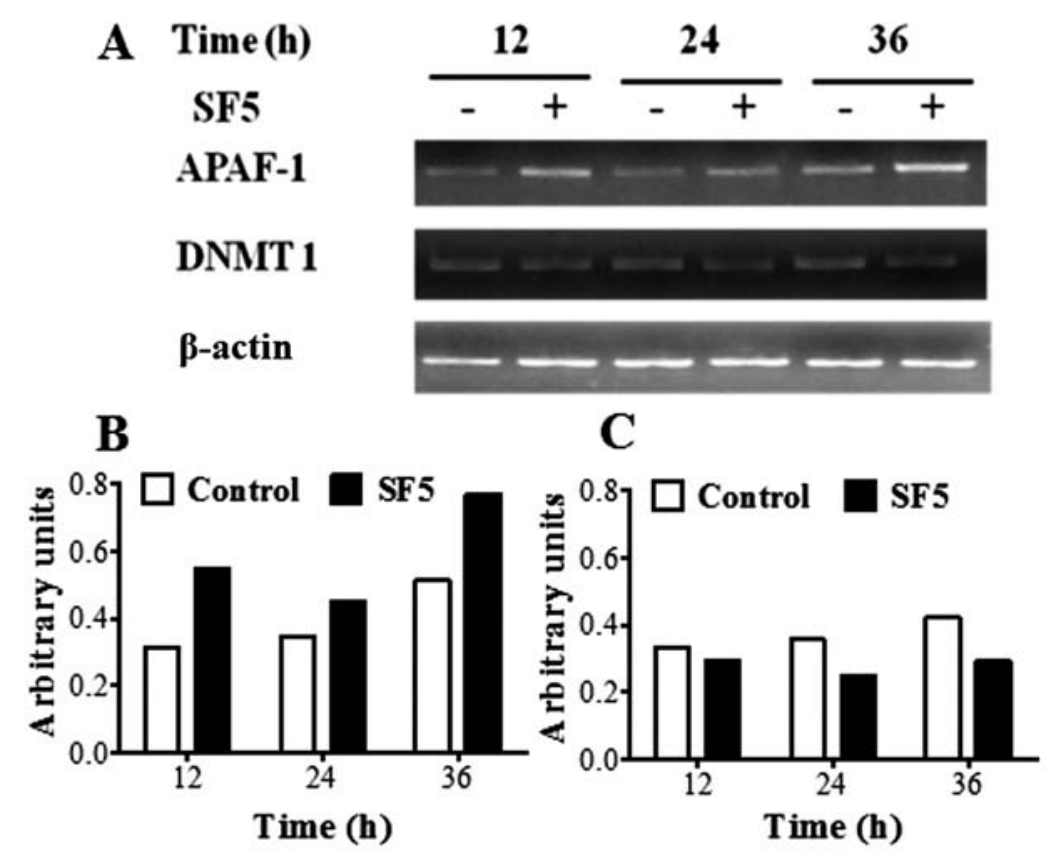

Figure 6. RT-PCR analysis of the DNMT1 and Apaf-1 mRNA expression in K562 cells treated with SF5 hexanic subfraction. (A) Agarose gel electrophoresis. Semi-quantitative analysis of: (B) Apaf-1 and (C) DNMT1 mRNAs. B-actin mRNA was used as loading control. Cells (2.5x10 $\left./ \mathrm{ml}^{2}\right)$ were cultured in the absence (control) or presence of SF5 $(50 \mu \mathrm{g} / \mathrm{ml})$. Representative results from four independent experiments.

inhibited leukemic cell proliferation (Fig. 2A), and this effect is frequently associated to apoptosis induction (21), the SF5 effects on apoptosis of K562 cells were also studied. Apoptosis is an active process of cell death detected by different methods (6) based on specific characteristics as cell shrinking, chromatin condensation, fragmentation of the cell nuclei (sub-G1 nuclei), membrane blebbing and PS exposure on the surface of cells $(5,22)$.

Mitochondrial membrane depolarization is an early apoptotic event, preceding PS exposure, caspase activation and DNA condensation (23). Then, the SF5 toxic effect on leukemic cells was evaluated (Fig. 2B) by mitochondrial reduction activity (MTT assay). This reaction depends on intact mitochondrial function and cell viability since mitochondrial MTT reduction by mitochondrial dehydrogenases depends on reduced coenzymes supplied by viable cell metabolism (18). The SF5 toxicity on leukemic cells was concentration-dependent and seemed to progress into apoptosis. Induction of K562 apoptosis by SF5 is demonstraded by cell shrinking, increased sub-G1 nucleus and PS exposure in the outer membrane leaflet. The translocation of PS, which possesses a high affinity for Annexin V, is a key signal for phagocyte recognition (24).

The apoptosis process involves several molecules with up- and down-regulatory properties. Stimulation of proapoptotic molecules or inhibition of anti-apoptotic factors is dependent of cell type and the form of insult (6). There are two distinct pathways for caspase activation: 1) death receptors such as Fas can trigger caspase 8, which in turn, activates caspase 3 ; 2) mitochondria can release apoptogenic factors like cytochrome $\mathrm{c}$ and Apaf-1, leading to inner mitochondrial membrane depolarization and activation of caspase 9, which also activates caspase 3 (25). Although the activation of the endonuclease does not require gene transcription or protein synthesis (26), de novo synthesis or activation of many other proteins including proteinases appears to be required to complete apoptosis (27). Apaf-1 expression is important for tumor suppression because it plays a central role in DNA damage-induced apoptosis (28). The Apaf-1 gene is inactivated in tumor progression and in the chemoresistance of some malignancies (29). SF5 clearly induced up-regulation of the Apaf-1 mRNA transcription in K562 cells (Fig. 6A and B). This pro-apoptotic molecule interacts with cytochrome $\mathrm{c}$ and ATP, integrating the apoptosome and converting pro-caspases to active caspases. Since Apaf-1 is a central component of the intrinsic pathway of apoptosis, this result suggests that SF5 is imputing K562 cells into apoptosis through the mitochondrial intrinsic pathway. This finding corroborates other reports showing anti-leukemic effect of agents by inducing apoptosis via the mitochondrial pathway (30).

SF5 reduced the DNMT1 mRNA expression (Fig. 6A and $\mathrm{C}$ ), a mammalian maintenance DNA methyltransferase. Structural features of the Apaf-1 promoter suggest that methylation of the $\mathrm{CpG}$ islands serves as the major mechanism of transcriptional regulation of Apaf-1 (3). The reduced expression of DNMT1 in K562 cells by SF5 treatment may be associated with hypomethylation of Apaf-1 promoter gene resulting in its overexpression and apoptosis of leukemic cells. Deregulation of Apaf-1 and DNMT1 gene transcription may be contributing to the anti-tumoral effect of SF5.

This study reports for the first time the furane diterpene methyl-6 $\alpha$-acetoxy-7ß-hydroxyvouacapan-17ß-oate (Fig. 1 and Table I) in Pterodon pubescens, previously described for Pterodon polygalaeflorus. Phytochemical studies of SF5 also indicated the presence of linear diterpenes (geranylgeraniol and farnesol derivatives), and the furane diterpenes 7ß-acetoxy- 
vouacapan, 6 $\alpha$-7ß-diacetoxyvouacapan-17ß-oate and methyl$6 \alpha$-acetoxy-7ß-hydroxyvouacapan-17ß-oate (Table I). These compounds were previously reported for Pterodon pubescens $(14,16,31)$. Both linear or cyclic diterpenes may be involved in the apoptotic effect of SF5 on leukemic cells since similar vouacapan diterpenes have induced cytotoxicity and apoptosis of melanoma cells and prostate cancer cell, respectively $(17,31)$, and apoptosis of leukemia U937 cells has been reported to geranylgeraniol (32).

In conclusion, this study provides important insights into molecular mechanisms of in vitro anti-leukemia effects of a terpenic fraction from Pterodon pubescens. The DNMT1 gene down-regulation and the overexpression of Apaf-1 mRNA, induced by SF5, suggest that it may induce apoptosis of leukemic cells by epigenetic regulation of pro-apoptotic proteins involved in the mitochondrial intrinsic pathway. A further challenge will be the evaluation of in vivo antitumor potency to confirm the potential chemotherapeutic action of SF5.

\section{Acknowledgements}

We would like to thank the LIA-BPPN for technical assistance. This study was supported by grants from Fundação de Amparo a Pesquisa do Estado do Rio de Janeiro (Grant no. E26/171.330/2006), Rio de Janeiro and Conselho Nacional de Desenvolvimento Científico e Tecnológico (Grant no. 474880/2008 7), Brasília, Brazil.

\section{References}

1. Arnoult D: Mitochondrial fragmentation in apoptosis. Trends Cell Biol 17: 6-12, 2006.

2. Schuler D and Szende B: Apoptosis in acute leukemia. Leuk Res 28: 661-666, 2004.

3. Furukawa Y, Sutheesophon K, Wada T, Nishimura M, Saito Y, Ishii $\mathrm{H}$ and Furukawa $\mathrm{Y}$ : Methylation silencing of the apaf-1 gene in acute leukemia. Mol Cancer Res 3: 325-334, 2005.

4. Robert MF, Morin S, Beaulieu N, Gauthier F, Chute IC, Barsalou A and MacLeod R: DNMT1 is required to maintain CpG methylation and aberrant gene silencing in human cancer cells. Nat Genet 33: 61-65, 2003.

5. Surh YJ, Hurh YJ, Kang JY, Lee E, Kong G and Lee SJ: Resveratrol, an antioxidant present in red wine, induces apoptosis in human promyelocytic leukaemia (HL-60) cells. Cancer Lett 140: $1-10,1999$.

6. Huerta S, Goulet EM, Huerta-Yepez S and Livingston EH: Screening and detection of apoptosis. J Surg Res 139: 143-156, 2007.

7. Mann J: Natural products in cancer chemotherapy: past, present and future. Nature 2: 143-148, 2002.

8. Pio Correa M: Dicionário das plantas úteis do Brasil e das exóticas cultivadas. In: Ministério da Agricultura Instituto Brasileiro de Desenvolvimento Florestal. Vol. 3, Rio de Janeiro, p129, 1984

9. Coimbra R: Notas de Fitoterapia. In: Catálogo dos Dados Principais Sobre Plantas Utilizadas em Medicina e Farmácia. Edição de Carlos Silva Araújo,p222, 1942.

10. Cruz GL: Livro Verde das Plantas Medicinais e Industriais do Brasil. Belo Horizonte, MG, 2: 779-780, 1965.

11. Sabino KCC, Castro FA, Oliveira JCR, Dalmau SRA and Coelho MGP: Successful therapy of collagen-induced arthritis in mice with a hydroalcoholic extract of seeds of Pterodon pubescens. Phytother Res 13: 613-615, 1999.

12. Coelho MGP, Sabino KCC and Dalmau SR: Immunomodulatory effects of sucupira (Pterodon pubescens) seed infusion on collagen induced arthritis. Clin Exp Rheumatol 22: 213-218, 2004 .
13. Silva MCC, Gayer CRM, Lopes CS, Calixto NO, Reis PA, Passaes CP, Dalmau SR, Sabino KC, Todeschini AR and Coelho MG: Acute and topic anti-edematogenic fractions isolated from the seeds of Pterodon pubescens. J Pharm Pharmacol 56: $135-141,2004$

14. Mors WB, dos Santos Filho MF, Monteiro HJ, Gilbert B and Pellegrino J: Chemoprophylactic agent in schistosomiasis: 14, 15-epoxygeranylgeraniol. Science 157: 950-951, 1967.

15. Fascio M, Gilbert B, Mors WB and Nishida T: Two new diterpenes from Pterodon pubescens Benth. An Acad Bras Cienc 42: 97-101, 1970.

16. Fascio M, Mors WB, Gilbert B, Mahajan JR, Monteiro MB dos Santos Filho D and Vichnewsky W: Diterpenoids furans from Pterodon pubescens species. Phytochemistry 15: 201-203, 1976.

17. Vieira CR, Marques MF, Soares PR, Matuda L, Oliveira CMA, Kato L, Silva CC and Guillo LA: Antiproliferative activity of Pterodon pubescens Benth. seed oil and its active principle on human melanoma cells. Phytomedicine 15: 528-532, 2008.

18. Mossman T: Rapid colorimetric assay for cellular growth and survival: application to proliferation and cytotoxicity assays. J Immunol Methods 65: 55-63, 1983.

19. Dalmau SR, Freitas CS and Savino W: Upregulated expression of fibronectin receptors underlines the adhesive capability of thymocytes to thymic epithelial cells during the early stages of differentiation: Lessons from sublethally irradiated mice. Blood 93: 974-990, 1999 .

20. Campos AM, Silveira ER, Braz-Filho R and Teixeira TC: Diterpenoids from Pterodon polygalaeflorus. Phytochemistry 36: 403-406, 1994.

21. Yan Q, Li Y, Jiang Z, SunY, Zhu L and Ding Z: Antiproliferation and apoptosis of human tumor cell lines by a lectin (AMML) of Astragalus mongholicus. Phytomedicine 16: 586-593, 2009.

22. Kerr JFR, Wyllie AH and Currie AR: Apoptosis: a basis biological phenomenon with wide-ranging implication in tissue kinetics. Br J Cancer 26: 239-257, 1972.

23. Vermeulen K, Strnad M, Havlícék L, Van Onckelen H, Lenjou M, Nijs G, Van Bockstaele DR and Berneman ZN: Plant cytokinin analogues with inhibitory activity on cyclin-dependent kinases exert their antiproliferative effect through induction of apoptosis initiated by the mitochondrial pathway: Determination by multiparametric flow cytometric analysis. Exp Hematol 30: 1107-1114, 2002.

24. Inayat-Hussain SH, Annuar BO, Din LB, Ali AM and Ross D: Loss of mitochondrial transmembrane potential and caspase 9 activation during apoptosis induced by the novel styryl-lactone goniothalamin in KL-60 leukemia cells. Toxicol in Vitro 17: 433-439, 2003

25. Philchenkov A: Caspases: potential targets for regulating cell death. J Cell Mol Med 8: 432-444, 2004.

26. Bursch W, Kleine L and Tenniswood M: The biochemistry of cell death by apoptosis. Biochem Cell Biol 68: 1071-1074, 1990.

27. Fesus L, Thomazy V and Falus A: Induction and activation of tissue transglutaminase during programmed cell death. FEBS Lett 224: 104-108, 1987.

28. Norbury CJ and Zhivotovsky B: DNA damage-induced apoptosis. Oncogene 23: 2797-2808, 2004.

29. Soengas MS, Capodieci P, Polsky D, Mora J, Esteller M, OpitzAraya X, McCombie R, Herman JG, Gerald WL, Lazebnik YA, Cordón-Cardó C and Lowe SW: Inactivation of the apoptosis effector apaf-1 in malignant melanoma. Nature 409: 207-211, 2001.

30. Carter BZ, Mak DH, Schober WD, McQueen T, Harris D, Estrov Z, Evans RL and Andreeff M: Triptolide induces caspase-dependent cell death mediated via the mitochondrial pathway in leukemic cells. Blood 108: 630-637, 2006.

31. Spindola HM, Carvalho JE, Ruiz ALTG, Rodrigues RAF, Denny C, Souza IMO, Tamashiro JY and Foglio MA: Furanoditerpenes from Pterodon pubescens Benth with selective in vitro anticancer activity for prostate cell line. J Braz Chem Soc 20: 569-575, 2009.

32. Masuda Y, Nakaya M, Aiuchi T, Hashimoto S, Nakajo S and Nakaya K: The mechanism of geranylgeraniol-induced apoptosis involves activation, by a caspase-3-like protease, of a c-Jun $\mathrm{N}$-terminal kinase signaling cascade and differs from mechanisms of apoptosis induced by conventional chemotherapeutic drugs. Leuk Res 24: 937-950, 2000. 